\section{Animal Intelligence}

I AM not aware whether or not the following "case has appeared among the numerous instances under this head already given in the columns of NATURE. It is to be found in Vogt and Specht's "Die Säugetiere in Wort und Bild" (p. II). The writer of the text of that work says :-- "I have myself seen a case in which a chimpanzee, who had got himself a little scratched by the point of a slightly projecting nail in the wall of his cage, first carefully examined the same, then sought to remove it, and afterwards, when he was let out, immediately proceeded t) search for the head of the nail on the outside of the wall, and then, on finding it, began to try to pull out the nail with his fingers and teeth, and when this was done for him with a pair of pincers, broke out into lively demonstrations of joy."

Camberwell, September I8

Geo. G. Chisholm

\section{THE BRITISH ASSOCIATION}

Southport, Tuesday.

CONSIDERING general results, the Southport meeting must be regarded as a decided success. The number of tickets sold has been over 2,650 , and the funds will therefore be ample to provide for scientific research. The supply of papers has been kept up in all Sections, and the quality of them has certainly reached a fair average. The weather with two exceptions has been fine, and the accommodation ample. The soirées have been all that could be wished, to which the beautiful trees, ferns, and palms in the Winter Gardens have contributed, and the exhibition connected with it afforded points of interest for people of varier tastes. The local officers have worked well and shown both application and forethought, and the excursions, if not of a particularly scientific character, have certainly been the means of the $\Lambda$ ssociation receiving much hospitality, and seeing many places of interest, and some of beauty.

The General Committee meeting on Monday was very largely attended, and after the exceedingly well expressed speeches of Principal Dawson and Sir Charles Tupper, the feeling was strong that the meeting in Canada will be a success, and that the greater the number who go the better will the Canadians be pleased. Sir Charles Tupper stated that, after a long experience of the Canadian House of Commons, he never saw a vote so unanimously passed as the appropriation of $4000 \mathrm{l}$. for the forthcoming meeting. There are many who still think it a mistaken policy for the Association to leave the shores of these islands, but all of those who were present fully sympathised with the very strong expression of approval that met announcement after announce ment of cheap passages, free railway journeys, and magnificent hospitality offered by the Dominion. General satisfaction was expressed at the announcement that those who are unable to spare the time for the long excursions to the Rocky Mountains and elsewhere after the Canada meeting will be allcwed to make those expeditions before the meeting, which will commence on August 27, under the presidency of Prof. Lord Rayleigh.

For the 1885 meeting Birmingham and Nottingham did not put in applications, the competing towns being Aberdeen and Bournemouth. In favour of the former it was urged that the members of the Association by that time will be so accustomed to long journeys that they will think nothing of the distance to Aberdeen, and that the Scotch meetings have always been a success, both as to numbers and as to the position of those who attended. In favour of Bournemouth it was urged that first meetings were always a great success, as at Brighton and the present meeting at Southport. The vote was for the northern University town; but there was an expression of feeling that the claims of the watering-place should not be forgotten in 1886 .

Prof. Ball's lecture was the most successful of the addresses delivered in the Pavilion. The building, as originally constructed, was oval in shape, with a gallery extending round it, and its acoustic properties were then good; subsequently an ordinary theatrical stage and appointments were added to it, which latter were only partially removed for the meeting, and the building was certainly but ill adapted for the large audiences which endeavoured to find room in it. The Reception Room at the Cambridge Hall left nothing to be desired, except a wish that it had been on the ground floor.

In the Geographical Section much interest was felt in a long paper by $\mathrm{Mr}$. H. H. Johnson, on a visit to $\mathrm{Mr}$. Stanley's stations on the River Congo. The author read a letter he had just received from Mr. Stanley, in which that explorer gives expression to his belief that the River Congo will give civilisation and commerce to the lost Continent. In this Section also an interesting paper was read by Mr. Wm. Hancock of the Chinese Imperial Custom Service, on the volcanic and earthquake regions of Central America; by the Rev. S. J. Perry, on Nos Vey and the south-west of Madagascar, which he visited for the late transit of Venus.

The address of Sir Frederick Bramwell to the working men was a very great success; his good voice and easy style told with effect on the crowded audience of working men who came to learn about the telephone, which was clearly shown to be an important factor in commercial life.

The following is the list of grants of money appropriated by the General Committee to scientific purposes for next year :-

\section{A-Mathematics and Physics}

Brown, Prof. Crum-Meteorological Observations on Ben Nevis

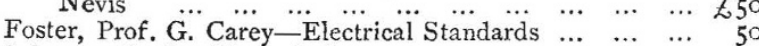

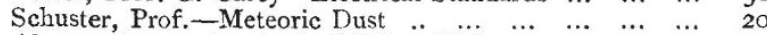

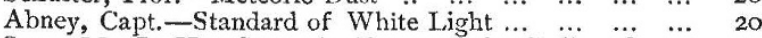
Scott, Mr. R. H. - Synoptic Charts of the Indian Ocean 50 Stewart, Prof. Balfour-Meteorolosical Observatory near Chepstow

Shoolbred, Mr. J. $\dddot{N}$. - Reduction of Tidal Observations Darwin, Prof. G. H.-Harmonic Analysis of Tidal Observations..

\section{$B$-Chemistry}

Odling, Prof.-Photographing the Ultra-Viulet Spark $\begin{array}{lllllllllll}\text { Spectra } & \ldots & \ldots & \ldots & \ldots & \ldots & \ldots & \ldots & \ldots & \ldots & \ldots\end{array}$

$$
\text { C-Geology }
$$

Etheridge, Mr. R.-Earthquake Phenomena of Japan $\quad \ldots \quad 75$ Williamson, Prof. W. C.-Fossil Plants of Halifax $\quad . .1$ I5 Sorby, Dr. H. C.--British Fossil Polyzoa... $\quad \ldots \quad \ldots \quad \ldots \quad \ldots \quad$ ro Prestwich, Prof.-Erratic Blocks... . . . . . . . . Rocks

Hull, Prof. E. - - Circulation of Underground waters $\quad \ldots$

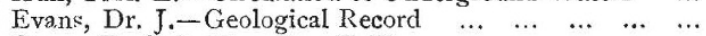
Green, Prof. A. H.-Raygill Fissure ... $\ldots \ldots \ldots$.... $\ldots$
Prestwich, Prof.-International Geological Map of Europe

$$
\text { D-Biology }
$$

Newton, Prof.-Zoological Bibliography

Sclater, P. L. - Natural History of Timor Laut

Lankester, Prof. Ray-Table at the Zoolugical Station at Naples

Harrison, J. Park-Facial Characteristics of Races in the British Isles

Hooker, Sir J.-Exploring Kilimandjaro and the adjoining

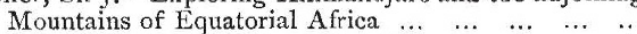

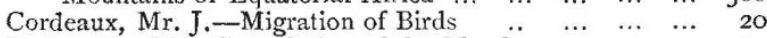

Foster, Dr. M.-Coagulation of the Blood $\begin{array}{lllll}\cdots & \ldots & \ldots & \ldots & 20 \\ \end{array}$

Stainton, Mr. H. T. - Record of Zoological Literature $\ldots$ roo

$$
\text { E-Geography }
$$

Godwin-Austen, Lieut.-Col.--Exploration of New Guinea 100

$$
\text { F-Economic Science and Statistics }
$$

Brabrook, Mr. E. W.-Preparation of the Final Report of $\begin{array}{lllllll}\text { the Anthropometric Committee } & \ldots & \ldots & \ldots & \ldots & \ldots & \text { I }\end{array}$ 


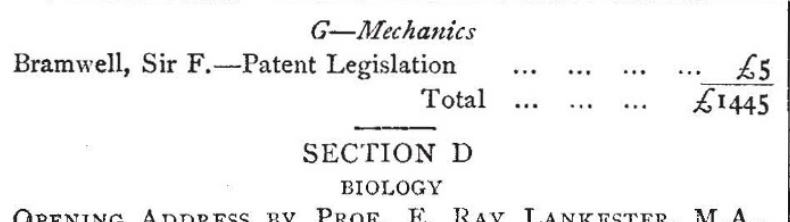

F.R.S., F.L.S., PRESIDENT OF THE SECTION.

IT has become the custom for the presidents of the various Sections of this Association to open the proceedings of the departments with the chatrmanship of which they are charged by formal addresses. In reflecting on the topics which it might be desirable for me to bring under your notice, as your president, on the present occasion, it has occurred to me that I might use this opportunity most fitly by departing somewhat from the prevailing custom of reviewing the progress of science in some special direction during the past year, and that, instead of placing before you a summary of the results recently obtained by the investigations of biologists in this or that line of inquiry, I might ask your attention and that of the external public (who are wont to give some kindly consideration to the opinions expressed on these occasions) to a matter which is even more directly connected with the avowed object of our Association, namely, "the Advancement of Science." I propose to place before you a few observations upon the provision which exists in this country for the advancement of that branch of science to which Section D is dedicated-namely, Biology.

I am aware that it is usual for those who speak of men of science and their pursuits to ignore altogether such sordid topics as the one which $I$ have chosen to bring forward. A certain pride on the one hand, and a willing acquiescence on the other hand, usually prcvents those who are professionally concerned with scientific pursuits from exposing to the public the pecuniary destitution and the consequent crippling and languor of scientific research in this country. Thuse Englishmen who take an interest in the progress of science are apt to suppose that, in some way which they have never clearly understood, the pursuit of scientific truth is not only its own reward, but also a sufficient source of food, drink, and clo:hing. Whilst they are interested and amused by the remarkable discoveries of scientific men, they are astonished whenever a proposal is mentioned to assign salaries to a few such persons sufficient to enable them to live decently while devoting their time and strength to investigation. The public are becoming more and more anxious to have the opinion or report of scientific men upon matters of commercial importance, or in relation to the public health; and yet in ninety-nine cares out of a hundred they expect to have that opinion for the asking, although accustomed to pay other profes:ional men handsomely for similar service. There is, it appears, in the public mind a vague belief that men who occupy their time with the endeavour to add to knowledge in this or that branch of science are mysteriously supported by the State Exchequer, and are thus fair game for attacking with all sorts of demands for gratuitous service; or, on the other band, the notion at work appears sometimes to be that the making of new knowledge-in fact, scientific discovery-is an agreeable pastime, in which some ingenious gentlemen, whose business in other directions takes up their best hours, find relaxation after dinner or on the spare hours of Sunday. Such mistaken views ought to be dispelled with all possible celerity and determination. It is in part owing to the fact that the real state of the case is not widely and persistently made known to the public, that no attempt is made in this country to raise scientific research, and especially biological research, from the condition of destitution and neglect under which it suffers-a condition which is far below that of these same interests in France and Germany, and even in Holland, Belgium, Italy, and Russia, and is discreditable to England in proportion as she is richer than other States.

It appears to me that, in placing this matter before you, I may remove myself from any suggestion of self-interest by at once stating that the great defect to which I shall draw your attention is not that the few existing public positions which are open in this country to men who intend to devote their chief energies to binlogical research are endowed with insufficient salaries; but that there is not anything like a sufficiently large number of those posts, and that there is in that respect, from a national point of view, a pecuniary starvation of biology, a withholding of money which (to use another metaphor) is no less the sinews of the war of science against ignorance than of other less glorious campaigns, Surely men engaged in the scientific profession may advocate the claim of science to maintenance and needful pecuniary provision! It seems to me that we should, if necessary, swallow, rather than be controlled by, that pride which tempts us to paint the scientific career as one far above and independent of pecuniary considerations; $\mathrm{x}$ hereas all the while we know that knowledge is languishing, that able men are drawn off from scientific research into other careers, that important discoveries are approached and their final grasp relinquished, that great men depart and leave no disciples or successors, simply for want of that which is largely given in other countries, of that which is most abundant in this country, and is so lavishly ex. pended on armies and navies, on the development of commercial resources, on a hundred injurious or meaningless charities-viz., money.

I have no doubt that I have the sympathy of all my hearers in wisbing for more extensive provision in this country for the prosecution of scientific research, and esfecially of biological research. I need hardly remind this audience of the almost romantic history of some of the great discoveries which have been made in reference to the nature and history of living things during the past century. The microscope, which was a drawing. room toy a hundred years ago, has, in the hands of devoted and gifted student: of nature, been the means of giving us knowledge which, on the one hand, has saved thousands of surgical patients from terrible pain and d $d$ ath, and, on the other hand, bas laid the foundation of that new philosophy with which the name of Darwin will for ever be associated. "When Ehrenberg and, later, Dujardin described and figured the various forms of Monas, Vibrio, Spirillum, and Bacterium which their microscopes revealed to them, no one could predict that fifty years later these organi-ms would be recognised as the cause of that dangerous suppuration of wounds wbich so often defeated the beneficent efforts of the surgeon and made an operation in a hospital ward as dangerous to the patient as residence in a plague-stricken city. Yet this is the result $\mathrm{w}$ hich the assiduous studies of the biologists, provided with laboratories and maintenance by Continental States, have in due time brought to light. Theodore Schwann, professc $r$ at Liége, first showed that these Bacteria are the cause of the putrefaction of organic substances, and subsequently the French chemist Pasteur, professor in the Ecole Normale of Paris, confirmed and extended Schwann's discovery, so as to establish the belief that all putrefactive changes are due to such minute organisms, and that if these organisms can be kept at bay no putrefaction can occur in any given substance.

It was reserved for our countryman, Joseph Lister, to apply this result to the treatment of wounds, and by his famous antiseptic method to destroy by means of special poisons the putrefactive organisms which necessarily find their way into the neighbourhood of a wound, or of the surgeon's knife and dressings, and to ward off by similar means the access of such organisms to the wounded surface. The amount of death, not to speak of the suffering short of death, which the knowledge of Bacteria gained by the microscope has thus averted is incalculable.

Yet further, the discoveries of Ehrenberg, Schwann, and Pasteur are hearing fruit of a similar kind in other directions. It seems in the highest degree probable that the terrible scourge known as tubercular consumption or phthisis is due to a parasitic Bacterium (Bacillus), discovered two years since by Koch of Berlin, as the immediate result of investigations which he was commissioned to carry on at the public expense, in the specially erected Laboratory of Public Health, by the German Imperial Government. The diseases known as erysipelas and glanders or farcy have similarly, within the past few months in German State-supported laboratories, been shown to re due to the attacks of special kinds of Bacteria. At present this knowledge has not led to a successful method of combating those diseases, but we can hardly doubt that it will ultimately do so. We are warranted in this belief by the fact that the disea e known as "splenic fever" in cattle and "malignant pustule" or anthrax in man has likewise been shown to be due to the action of a special kind of Bacterium, and that this knowledge has, in the hands of MM. Toussaint and Pasteur, led to a treatment in relation to this disease similar to that of vaccination in relation to small-pox. By cultivation a modified growth of the anthrax parasite is obtained, which is then used in order to inoculate cattle and sheep with a mild form of the disease, such inoculation laving the result of rendering the cattle and : heep free from the attaclis of the severe form of disease, just as vaccination or inoculation with cow-pox protects man from the attack of the deadly smallpox. One other case I may call to mind in which knowledge 
of the presence of Bacteria as the cause of disease has led to successful curative treatment. A not uncommon affliction is inflammation of the bladder accompanied by ammoniacal decomposition of the urine. Microscopical investigation has shown that this ammoniacal decomposition is entirely due to the activity of a Bacterium. Fortunately this Bacterium is at once killed by weak solutions of quinine, which can be injected into the bladder without causing any injury or irritation. This example appears to have great importance, because it is the fact that many kinds of Bacteria are not killed by solutions of quinine, but require other and much more irritant poisons to destroy their life, which could not be injected into the bladder without causing disastrous effects. Since some Bacteria are killed by one poison and some by another, it becomes a matter of the keenest interest to find out all such poisons ; and possibly a nong them may be some which can be applied so as to kill the Bacteria which produce phthisis, erysipelas, glanders, anthrax, and other scourges of humanity, whilst not acting injuriously upon the body of the victim in which these infinitesimal parasites are doing their deadly work. In such ways as this biology has turned the toy "magnifying-glass" of the last century into a saver of life and health.

No less has the same agency revolutionised the thoughts of men in every branch of philosophy and speculation. The knowledge of the growth of the chick from the egg and of other organisms from similarly constituted beginnings has been slowly and continuously gained by prodigious labour, extending over generation after generation of students who have occupied the laboratories and lived on the stipends provided by the Governments of European States-not English, but chiefly German. It is this history of the development of the individual animal and plant from a simple homogeneous beginning to a complex heterogeneous adult which has furnished the starting-point for the wide-reaching Doctrine of Evolution. It is this knowledge, coupled with the knowledge of the myriad details of structure of all kinds of animals and plants which the faithful occupants of laboratories and the guardians of biological collections have in the past hundred years laboriously searched out and recordedit is this which enabled Darwin to propound, to test, and to firmly establish his theory of the origin of species by natural selection, and finally to bring the origin, development, and progress of man also into the area of physical science. I have said enough, in referring only to two very diverse examples of the far-reaching $\mathrm{c}$ nnsequences flowing from the discoveries of single-minded investigators in biological science, to remind my hearers that in the domain of biology, as in other sciences, the results attained by those who have laboured simply to extend our knowledge of the structure and properties of living things, in the faith that every increase of knowledge will ultimately bring its blessing to humanity, have in fact led with astonishing rapidity to conclusions affecting most profoundly both the bodily and the mental welfare of the community.

We who know the beneficent results which must flow more and more from the labours of those who are able to create new knowledge of living things, or, in other words, are able to aid in the growth of biological science, must feel something more than regret--even indignation-that England should do so small a proportion of the laborious investigation which is necessary, and is being carried on for our profit by other nationalities. It must not be supposed, because we have had our Harvey and our Darwin, our Hunter and our Lister, that therefore we have done and are doing all that is needful in the increase of biological science. The position of this country in relation to the progress of science is not to be decided by the citation of great names.

We require to look more fully into the matter than this. The question is not whether England has produced some great discoverers, or as many as any other nationality, but whether we might not, with advantage to our own community and that of the civilised world generally, do far more in the field of scientific investigation than we do.

It may be laid down as a general proposition, to which I know of no important exception, that scientific discovery has only been made by one of two classes of men, namely-(I) those whose time could be devoted to it in virtue of their possessing inherited fortunes; (2) those whose time could be devoted to it in virtue of their possessing a stipend or endowment especially assigned to them for that purpose.

Now it is a very remarkable fact that in England, far more than in any other country, the possessors of private fortune have devoted themselves to scientific investigation. Not only have we in all parts of the country numerous dilettanti ${ }^{1}$ who, especiaily in various branches of biology, do valuable work in continually adding to knowledge, quietly pursuing their favourite study without seeking to reach to any great eminence, but it is the fact that many of the greatest names of English discoverers in science are those of men who held no professional position designed to maintain an investigator, but owed their opportunity simply to the fact that they enjoyed a more or less ample income by inheritance. Thus, Harvey possessed a private fortune, Darwin also, and Lyell. Such also is true of some of the English naturalists, who more recently have most successfully devoted their energies to research. Those who wish to defend the present neglect of the Government and of public institutions to provide means for the carrying on of scientific research in this country are accustomed to declare as a justification for this neglect that we do very well without such provision, inasmuch as the cultivation of science here flourishes in the hands of those who are in a position of pecuniary independence. The reply to this is obvious. If those few of our countrymen who by accident are placed in an independent position show such ability in the prosecution of scientific research, how much more would be effected in the same direction were the machin ry provided to enable those also who are not accidentally favoured by fortune to enter upon the same kind of work ? The number of wealthy men who have distinguished themselves in scientific research in England is simply evidence that there is a natural ability and liking for such work in the English character, and is a distinct encouragement to those who have it in their power to do so to offer the opportunity of devoting themselves to research to a larger number of the members of the community. It is impossible to doubt that there are hundreds of men amongst us who have as great capacity for scientific discovery a; those whom fortune has favoured with leisure and opportunity. It cannot be doubted that, were the means provided to enable even a proportion of such men to give themselves up to scientific investigation, great discoveries of no less importance to the world than those relative to the causes of disease and the development of living things from the egg-which I have cited - would be made as a direct consequence of their activity, whereas now we must wait until in due course of time these discoveries shall be made for us in the laboratories of Germany, France, or Russia.

It should further be pointed out that it is altogether a mistake to suppose that the exi-tence amongst us of a few very eminent men is any evidence that we are contributing largely to the hard work of careful study and observation which really forms the material upon which the conclusions of eminent discoverers are based. You will find in every department of biological knowledge that the hard work of investigation is being carried on by the well-trained army of German observers. Whether you ask the zoologist, the botanist, the lhysiologist, or the anthropologist, you will get the same answer: it is to Gernan sources that he looks for new information; it is in German workshops that discoveries, each small in itself, but gradually leading up to great conclusions, are daily being made. To a very large extent the business of those who are occupied with teaching or applying biological science in this country consists in making known what has been done in German Jaboratories; our English students flock to Germany to learn the methods of scientific research; and to such a state of werkness is English science reduced for want of proper nurture and support, that even on some of the rare occasions when a capable investigator of biological problems has been required for the public service, it has been necessary to obtain the assistance of a foreigner trained in the laboratories of Germany.

Let me now briefly explain what are the arrangements, in number and in kind, which exist in other countries for the purpose of promoting the advancement of biological science, which are wanting in this country.

In the German Empire, with a population of 45,000,000, there are twenty-one universities. These universities are very different from anything which goes by the name in this country. Amongst its other arrangements devoted to the study and teaching of all branches of learning and science, each university has five institutes, or establishments, devoted to the prosecution of researches in biulogical science. The e are respectively the physiological, the zoological, the anatomical, the pathological,

I I use this word in its best and truest sense, and would refer those who have been accustomed to associate with it some implication of contempt, to the wise and appreciative remarks of Goethe on Dilettanti. 
and the botanical. In one of these universities of average size, each of the institutes named consists of a spacious building containing many rooms fitted as workshops, provided with instruments, a museum, and, in the last instance, with an experimental garden. All this is provided and maintained by the State. At the head of each institute is the university professor respectively of physiology, of zoology, of anatomy, of pathology, or of botany. He is paid a stipend by the State, which in the smallest university is as low as $120 \%$., but may be in others as much as $700 l$., and averages say $400 l$. a year. Considering the relative expenditure of the professional classes in the two countries, this average may be taken as equal to $800 l$. a year in England. ${ }^{1}$ Besides the professor, each institute has attached to it, with salaries paid by the State, two qualified assistanis, who in course of time will succeed to independent positions. A liberal allowance is also made to each institute by the State for the purchase of instruments, material for study, and for the pay of servants, so that the total expenditure on profe:sor, assistants, laboratory service, and maintenance, averages $800 l$. a year for each institute-reaching as much as $2000 l$. or $3000 \%$. a year in the larger universities. It is the business of the professor, in conjunction with his assistants and the advanced students, who are admitted to work in the laboratories free of charge, to carry on investigations, to create new knowledge in the several domains of physiology, zoology, anatomy, pathology, and botany. It is for this that the professor receives his stipend, and it is on his success in this field of labour that his promotion to a more important or better paid post in another university depends. In addition to and irrespectively of this part of his duties, each professor is charged with the delivery of courses of lectures and of elementary instruction to the general students of the university, and for this he is all wed to charge a certain fee to each student, which he receives himself ; the total of such fees may, in the case of a largely attended university and a popular subject, form a very important addition to the professorial income; but it is distinctly to be understood that such payment by fees is only an addition to the professor's income, quite independent of his stipend and of his regular occupation in the laboratory : it is paid from a separate source and for a separate object. There are thus in the German Empire more than roo sucb institute: devoted to the prosecution of biological discovery, carried on at an anuual cost to the State of about $80,000 l$., equal to about $160,000 l$. in England, providing po.ts of graduated value for 300 investigators, some of small value, sufficient to carry the young student through the earlier portion of his career, whilst he is being trained and acting as the assistant of more experienced men-others forming the sufficient but not too valuable prizes which are the rewards of continuous and successful iabour.

In addition to these university institutes, there are in Germany such special laboratories of research, with duly salaried staff of investigators, as the Imperial Sanitary Institute of Berlin, and the large museums of Berlin, Bremen, and other large town:, corresponding to our own British Museum of Natural History.

Moreover, we must be careful to note, in making any comparison with the arrangements existing in England, that there are, in addition to the universities in Germany, a number of other educational institutions, at least equal in number, which are known as polytechnic schools, technical colleges, and agricultural colleges. These furnish posts of emolument to a limited number of biological students, who give courses of instruction to their pupils, but they have not the same arrangements for research as the universities, and are closely similar to those colleges which have been founded of late years in the provincial towns of England, such as Bristol, Nottingham, and Leeds. The latter are sometimes quoted by sanguine persons, who are satisfied with the reglected condition of scientific training and research in this country, as really sufficient and adequate representalives of the German universities. As a matter of fact, the excellent English colleges in question do not present anything at all comparable to the arrangements of a German university, and are, in respect of the amount of money which is expended upon them, the number of their teaching staff and the efficiency of their laboratories, inferior not merely to the smallest German university, but inferior to many of the technical schools of that country.

Passing from Germany, I would now ask your attention for a moment to an institution which is supported by the French

I From the fact that the salaries of judges, civil servants, military and naval officers, parsons and schoolmasters, as also the fees of physicians and lawyers, are in Germany even less than half what is paid to their representatives in England, I think that we are justified in making this estimate.
Government, and which-quite irrespective of the French university system, which is not on the whole superior to our own-constitutes one of the most effective arrangements in any European State for the production of new knowledge. The institution to which Iallude is the College de France in Paris-co-existing there with the Sorbonne, the École de Médecine, the École Normale, the Jardin des Plantes, and other State-supported institutionsin which opportuvity is provided for those Frenchmen who have the requisite talent to pursue scientific discovery in the department of biology, and in other branches of science. I particularly mention the College de France, because it appears to me that the foundation of such a college in London would be one of the simplest and most direct steps that could be taken towards filling, in some degree, the void from which Lnglish science suffers. The College de France is divided into a literary and a scientific faculty. Each faculty consists of some twenty professors. Each professor in the scientific faculty is provided with a laboratory and assistants (as many as four assistants in some cases), and with a considerable allowance for the expenses of the instruments and materials required in research. The personal stipend of each professor is $£ 400$, which has been increased by an additional $f_{1}$ Ioo a year in some cases from the Government Department charged with the promotion of higher studies. The professors in this institution, as in the German universities, when a vacancy occurs, have the right of nominating their future colleague, their recommendation being accepted by the Government. The professors are not expected to give any elementary instruction, but are directed to carry on original investigations, in prosecuting which they may as ociate with themselves pupils who are sufficiently advanced to join in such work; and it is further the duty of each professor to give a course of forty lectures in each year upon the re:ults of the researches in which he is engaged. There are at iresent among the professors of the College de France four of the most distinguished among contemporary students of hiological science: Professor Brown-Séquard, Professor Marey, Professor Balbiani, and Professor Ranvier. Every one who is acquainted with the progress of discovery in physiology, minute anatomy, and embryology, will admit that the opportunities afforded to these men have not been wasted; they have, as the result of the position in which they have been placed, produced abundant and most valuable work, and have, in addition, trained younger men to carry on the same line of activity. It was here, too, in the College de France, that the great genius of Claude Bernard found the necessary conditions for its development.

Let us now see how many and what kind of institutions there are in England devised so as to promote the making of new linowledge in biological science. Most persons are apt to be deceived in this matter by the fact that the terms "university," "professorship," and "college " are used very freely in England in reference to institutions which have no pecuniary resources whatever, and which, instead of corresponding to the German arrangements which go by these names, are empty titles, neither backed by adequate subsidy of the State nor by endowment from private sources.

In England, with its 25,000,000 inhabitants, there are only four universities which possess endowments and professoriatesviz., Oxford, Cambridge, Durham, and the Victoria (Owens College). Besides these, which are variously and specially organised each in its own way, there are the London Colleges (University and King's), the Normal School of Science at South Kensington, and various provincial colleges, which are to a small and varying extent in possession of funds which could be or are used to promote scientific research. Amongst all these variously arranged in titutions there is an extraordinarily small amount of provision for biological research. In London there is one professorship only, that at the Normal School of Science, which is maintained by a stipend paid by the State, and has a laboratory and salaried assistants, similarly maintained, in connection with it. The only other posts in London which are provided with stipends intended to enable their holders to pursue researches in the domain of biological science, are the two chairs of physiology and of zoology at University College, which, through the munificence of a private individual ( $\mathrm{Mr}$. Jodrell), have been endowed to the extent of $300 l$. a year each. To these should be added, in our calculation, certain posts in connection with the British Museum of Natural History and the Royal Gardens at Kew, maintained by the State; though it must be remembered that a large part of the expenditure in those institutions is necessarily taken up in the preservation of great national collections, and is not applicable to the subvention of investigators. We may, however, reckon about six posts, great and small, in the British 
Muieum, and four at Kew, as coming into the category which we have in view. In London, then, we may reckon approxim. ately some fourteen or fifteen subsidised posts for biological research. In Oxford there fall under this cat sgory the professorship of anatomy and his assistant, that of physiology, that of zoology, that of botany. The Oxford professorships are well supported by endowment, averaging $700 \%$ or $800 l$. a year; but they are inadequately provided with assi-tance as compared with corresponding German positions. Whilst Oxford has thus five posts, Cambridge has at present the same number, though the stipends are of less average value. In regard to Durham, it d'ses not appear that the biological professorships (which have their seat in the Newcastle College of Science) are supported by stipends derived from endowment: they fall under another category, to which allusion will be made below, of purely teaching positions, supported by the fees paid for such teaching by pupils. The Victoria University (Owens College, Manchester), supports its professors of physiology, anatomy, zoology, botany, and pathology, by means partly of endowment, partly of pupils' fees. By the provision of adequate laboratories and of salaries for assistants to each professor, and of studentfellowships, Owens College gives direct support to original investigation. We may reckon five major and eight minor posts as dedicated to biological research in this college. Altogether, then, we have 15 positions in Lordon and 23 in the provinces (taking assistantships, and professorships, and curatorships together) - a total of 38 in all England with its $25,000,000$ inhabitants, as against the 300 in Germany with its $45,000,000$ inhabitants. In proportion to its populaticn (leaving aside the consideration of its greater wealth), England has only about one-fourth of the provision for the advancement of biological research which exists in Germany.

It would not be fair to reckon in this comparison the various biological professorships in small colleges recently created, and paid to a small extent by stipends derived from endowments, in the provincial towns of England, for the holders of these chairs are called upon to teach a variety of subjects, for instance, z sology, botany, and geology combined; and not only is the devotion of the energies of their teaching staff to scientific discovery not contemplated in the arrangement of these institutions, but, as a matter of fact, the large demands made on the professors in the way of teaching must deprive them of the time necessary for any serious investigation. Such posts, in the fact that neither time, assistants, nor proper laboratories are provided t) enable their holders to engage in scientific research, are schoolmaster:hips rather than professorships, as the word is $\mathrm{u}$ sed in German universities.

One result of the exceedingly small provision of positions in England similar to those furnished by the German university system, and of the irregular, uncertain character of many of those which do exist, is that there is an insufficient supply of young men willing to enter upon the career of zoologist, botanist, physiolngist, or pathologist as a profession. The number of pusts is too small to create a profesion, i.e. an aveitue of success; and consequently, whereas in Germany there is always a large body of new men ready to fill up the vacancies as they occur in the professorial organisation, in England it very naturally does not appear to our university students as a reasonable thing to enter upon research as a profession, when the chances of employment are so few and far between.

Before stating, as I propose to do, what appears to me a reasonable and proper method of removing to some extent the defect in our national life due to the want of provision for scientific research, I will endeavour to meet some of the objections which are usually raised to such views as those which I am advocating. The endowment of research by the State, or from public funds of any kind, is opposed on various ground: One is that such action on the part of the Government is well enough in Continental States, but is con rary to the spirit of English statecraft, which leaves scientific as well as other enterprise to the individual initiative of the people. 'This ubjection is based on error, both as to fact and theory. It is well enough to leave to individual effort the conduct of such enterprises as are remunerative to the parties who condict them; but it is a mistake to speak of scientific research as an "enterprise" at all. The mistake arises from the extraordinary pertinacity with which so-called "invention" is confounded with the discovery of scientific truth. New knowledge in biological or other branches of science cannot be sold; it has no marketable value. Koch could not have sold the discovery of the Bacterium of phthisis for as much as sixpence, had he wished to do so
Accordingly, we find that there is not, and never has been, any tendency among the citizens of this country to provide for them. selves institutions for the manufacture of an article of so little pecuniary value to the individual who turns it out as is new knowledge. On the other hand, as a matter of fact, the providing of means for the manufacture of that article is not only not foreign to English statecraft, but is largely, though not largely enough, undertaken by the English State. The Royal Observatories, the British Museum, the Royal Gardens at Kew, the Geological Survey, the Government grant of 4,00ol. a year to the Royal Society, the $300 \%$. or $400 l$. a year (not a large sum) expended through the medical officer of the Privy Council upon the experimental investigation of disease, are ample evidence that such providing of means for creating new knowledge forms part of the natural and recognised responsibilities of the British Government. Such a responsibility clearly is recognised in this country, and does fall, according to the present arrangement of things, upon the central Government. What we have to regret is, that those who temporarily hold the reins of government fail to perceive the lamentable inadequacy of the mode in which this respon:ibility is met.

A second objection which is made to the endowment of research by public funds, or by other means, such as voluntary contributions, is this : it is stated that men engaged in scientific research ought to teach, and thus gain their livelihood. It is argued, in fact, that there is no need whatever to provide stipends or laboraturies for researchers, since they have only to stand up and teach in order to make incomes sufficient to keep them and their families, and to provide themselves with laboratories. This is a very plausible statement, because it is the fact that some investigators have also been excellent lecturers, and have been able to make an income by teaching whilst carrying on a limited amount of scientific investigation. But neither by teaching in the form of popular lectures, nor by teaching university or professional students who desire as a result to pass some examination test, is it possible, where there is a fair field and no favour, for a man to gain a reasonable iucome and at the same time to leave himself time and energy to carry on original investigations in science.

In some universities, such as those of Scotland, the privilege of conferring degrees of pecuniary value to their possessors becomes a source of income to the professors of the university; they are, in fact, able to make considerable incomes, independently of endowment, by compelling the candidates for degrees to pay a fee to each professor in the faculty for the right of attending his lectures and of presentation to the degree. Consequently, teaching here appears to be producing an income which may support a researcher; in reality, it is the acquisition of the university degree, and not necessarily the teaching, for which the pupil pays his fee. Where the teacher is unprotected by any compulscry regulations (such as that which requires attendance on his lectures and fee-payment on the part of the pupils) it is impossible for him to obtain such an income by teaching for one hour a day as will enable him to devote the rest of the day to unremunerative study and investigation, for the following reason. Other teachers, equally satisfactory as teacher:, will enter into competition with him, without having the same intention of teaching for one hour only, and of carrying on researches for the rest of the day. They will contemplate teaching for six hours a day, and they will accordingly offer to those who require to be taught either six hours' teaching for the same fee which the researcher charges for one, or one hour for a sixth part of that fee. Consequently the unprotected researcher will find his lecture-room deserted-pul ils will naturally go to the equally good teacher who gives more teaching for the same fee, or the same teaching for a less cost. And no one can say that this is not as it should be. The university pupil requires a certain cour: e of instruction, which he ought to be able to buy at the cheapest rate. It does not seem to be doing justice to. the pupil to conipel him to form one of a class consisting of some hundreds of hearers, where he can obtain but little personal supervision or attention from the teacher, whereas if he had the free di-posal of his fee, he might obtain six times the amount of attention from another teacher. This arrangement does not seem to be justifiable, even for the purpose of providing the university professor with an income and leisure to pursue scientific research. The student's fee should pay for a given amount of teaching at the market value, and he has just cause of complaint if, by compulsory enactments, he is taxed to provide the country with scientific investigation.

Teaching must, in all fairness, ultimately be paid for as 
teaching, and scientific research must be provided for out of other funds than those extracted from the pockets of needy students, who have a reasonable right to demand, in return for their fees, a fall modicum of instruction and direction in study.

In the German universities, the professor receives a stipend which provides for him as an investigator. He also gives lectures, for which he charges a fee, butino student is compelled to attend those lectures as a condition of obtaining his degree. Accordingly, independent teachers can, and do, compete with the professor in providing for the students' requirements in the matter of instruction. As a consequence, the fees charged for teaching are exceeding small, and the student can feel assured that he is obtaining his money's worth for his money. He is not compelled to pay any fee to any teacher as a condition of his promotion to the university degree. In a German university, if the professor in a given subject is incompetent, or the class overcrowded, the student can take his fee to a private teacher, and get better teaching; all that is required of the candidate, as a condition of his promotion to the Doctor's degree, is that he shall satisfy the examination-tests imposed by the faculty, and produce an original thesis.

Unless there be some such compelling influence as that obtaining in the Scotch universities, enabling the would-be researcher to gather to him pupils and fees without fear of competition, it seems impossible that he should gain an income by teaching whilst reserving to himself time and energy for the pursuit of scientific inquiry. It is thus seen that the necessity of endowment, in some form or another, to make provision for scientific research, is a reality, in spite of the suggestion that teaching affords a means whereby the researcher may readily provide for himself. The simple fact is that a teacher can only make a sufficient income by teaching, on the condition that he devotes his whole time and energy to that occupation.

Whilst I feel called upon to emphatically distinguish the two functions-viz., that of creating new knowledge, and that of distributing existing knowledge-and to maintain that it is only by arbitrary and undesirable arrangemente, not likely to be tolerated, or, at any rate, extended, at the present day, that the latter can be made to serve as the support of the former, I must be careful to point out that I agree most cordially with those who hold that it is an excellent thing for a man who is engaged in the one to give a certain amount of time to the other. It is a matter of experience that the best teachers of a subject are, coteris paribus, those who are actually engaged in the advancement of that subject, and who have shown such a thorough understanding of that subject as is necessary for making new knowledge in connection with it. It is also, in most cases, a good thing for the man engaged in research to have a certain small amount of change of occupation, and to be called upon to take such a survey of the subject in connection with which his researches are made, as is involved in the delivery of a course of lectures and other details of teaching. Though it is not a thing to be con. templated that the researcher shall sell his instruction at a price sufficiently high to enable him to live by teaching, yet it is a good thing to make teaching an additional and subsidiary part of his life's work. This end is effected in Germany by making it a duty of the professor, already supported by a stipend, to give some five or six lectures a week during the academical session, for which he is paid by the fees of his hearers. The fees are low, but are sufficient to be an inducement ; and, inasmuch as the attendance of the students is not compulsory, the profe-sor is stimulated to produce good and effective lectures at a reasonable charge, so as to attract pupils who would seek instruction from some one else if the lectures were not good or the fees too high. Indeed, in Germany this system works so much to the advantage of the students, that the private teachers of the universities at one time obtained the creation of a regulation forbidding the professors to reduce their fees below a certain minimum, since, with so low a fee as some professors were charging, it was impossible for a private teacher to compete! This state of things may be compared, with much advantage, with the condition of British universities. In these we hear, from one direction, complaints of the high fees charged and of the in. effective teaching given by the professoriate; and in other universities, where no adequate fees are allowed to the professors as a stimulus to them to offer useful and efficient teaching, we find that the teaching has passed entirely out of their hands into those of college tutors and lecturers. The fact is that a satisfactory relation between texching and research is one which will not naturally and spostaneously arrange itself. It can hardly be said to exist in any British university or college, but the method has been thought out and carried into practice in Germany. It consists in giving a competent researcher a stipend and a laboratory for his research work, and then requiring him to do a small amount of teaching, remunerated by fees proportionate to his ability and the pains which he may take in his teaching. If you pay him a fixed sum as a teacher, or artifically insure the attendance of his class, instead of letting this part of his income vary simply and directly with the attractiveness of his teaching, you will find as the result that (with rare exceptions) he will not give effective and useful teaching. He will naturally tend to do the minimum required of him, in a perfunctory u ay. On the other hand, if you leave him without stipend as a researcher, dependent on the fees of pupils for an income, he will give all his time and energies to teaching, be will cease to do any researcb, and become, pro tanto, an inferior teacher.

A third objection which is sometimes made to the proposition that scientific research must be supported and paid for as such, is the following: It is believed by many persons that a man who occupies his best energies in scientific research can always, if he choose, make an income by writing popular books or newspaper articles in his spare hours; and, accordingly, it is gravely main tained that there is no need to provide stipends and the means of carrying on their work for researchers. To do so, according to this view, would be to encourage them in an exclusive reticence, and to remove from them the inducement to address the public on the subject of their researches, by which the public would lose valuable instruction.

This view has been seriously urged, or I should not here notice it. Any one who is acquainted $u$ ith the sale of scientific books, and the profits which either author or publisher makes by them, knows that the suggestion which I have quoted is ludicrous. The writing of a good book is not a thing to be done in leisure moments, and such as have been the result of original research have cost their authors often years of labour apart from the mere writing. Mr. Darwin's books, no doubt, have had a large sale; but that is due to the fact, apart fron. the exceptional genius of the man who wrote them, that they represent some thirty or more sears of hard work, during which he was silent. There is not a sufficiently large public interested in the progress of science to enable a researcher to gain an income by writing books, however great his literary facility. A school-book or class-book may now and then add more or less to the income of a scientific investigator; but he who becomes the popular exponent of scientific ideas, except in a very moderate and limited degree, must abandon the work of creating new knowledge. The professional littérateur of science is as much removed by his occupation from all opportunity of serious investigation as is the professional teacher who has to consume all his time in teaching. Any other profes-ion-such as the Bar, Medicine, or the Church-is more likely to leave one of its followers time and means for scientific research than is that of either the popular writer or the successful teacher.

We have, then, seen that there is no escape from the necessity of providing stipends and laboratories for the purpose of creating new knowledge, as is done in continental States, if we are agreed that more of this new knowledge is needed and is among the products which a civilised community is bound to turn out. both for its own benefit and for that of the community of States, which give to and take from one another in such matters.

There are some who would finally attack our contention by denying that new knowledge is a good thing, and by refusing to recognise any obligation on the part of England to contribute her share to that common stock of increasing knowledge by which she necessarily profits. Among such persons are those who would prohibit altogether the pursuit of experimenta ? physiology in England, and yet would not and do not hesitate to avail themselves of the services of medical men, whose power of rendering those services depends on the fact that they have learnt the results obtained by the experiments of physiologists in other countries or in former times. In reference to this strange contempt and even batred of science, which undoubtedly has an existence among some persons of consideration, even at the present day, I shall have a few words to say before concluding this address. I have now to ask you to listen to what seems to me to be the demand which we should make, as members of a British Association for the Advancement of Science, in respect of adequate provision for the creation of new knowledge in the field of biology in England.

Taking England alone, as distinct from Scotland and Ireland, we require in order to be approximately on a level with Germany, forty new biological institutes, distributed among the five 
branches of physiology, zoology, anatomy, pathology, and botany-forty in adtition to the fifteen which we may reckon (taking one place with another) as already existing. The average cost of the buildings required would be about $4,000 l$. for each, giving a total initial expenditure of $160,000 l$; the average cost of stipend; for the director, assistants, and maintenance we may calculate at $1,500 \%$. annually for each, or $60,000 \%$. for the forty-equal to a capital sum of $2,000,000 l$. These in titutes should be distributed in groups of five-eight groups in all-throughout the country. One such group would be placed in London (which is, at present, almost totally destitute of such arrangements), one in Bristol, one in Birmingham, one in Nottingham, one in Leeds, one in Newcastle, one in zpswich, one in Cardiff, one in Plymouth -in fact, one in each of the great towns of the kingdom where there is at present, or where there might be with advantage, a centre of professional education and higher study. The first and the most liberally arranged of these biological institutes-embracing its five branches, each with its special laboratory and staff-should be in London. If we can have nothing else, surely we may demand, with some hope that our request will eventually obtain compliance, the formation in London of a College of Scientific Research similar to that of Paris (the Collège de France). It is one of the misfortunes and disgraces of London that-alone amongst the capitals of Europe, with the exception of Constantinople - it is destitute of any institution corresponding to the universities and colleges of research which exist elsewhere.

Either in connection with a properly organised teaching mniversity or as an independent institution, it seems to me a primary need of the day that the Government should establish in London laboratories for scientific research. Two hundred and fifty years ago Sir Thomas Gresham founded an institution for scientific research in the City of London. The property which he left for this purpose is now estimated to be worth three millions sterling. This property was deliberately appropriated to other uses by the Corporation of the City of I.ondon and the Mercers' Company about a hundred years since, with the consent of hoth Houses of Parliament. By this outrageous act of spoliation these Corporations, who were the trustees of Gresham, have incurred the curse which he quaintly inserted in his will in the hope of restraining them from attempts to divert his property, from the uses to which he destined it. "Gresham's curse" rans as follows:- "And that I do require and charge the said Corporations and cbief governors thereof, with circumspect Diligence and without long Delay, to procure and see to be done and obtained, as they will answer the same before Almighty God; (for if they or any of them should neglect the obtaining of such Licenses or Warrants, which I trust can not be difficult, nor so chargeable, but that the overplus of my Rents and Profits of the Premisses hereinbefore to them disposed, will soon reconpense the same; because to soe good Purpose in the Commonwealth, no Prince nor Council in any Age, will deny or defeat the same. And if conveniently by my Will or other Convenience, I might assure it, I would not leave it to be done after my death, then the same shall revert to my heirs, whereas I do mean the same to the Commonwealth, and then THE DeFault THEREOF SHALl BE TO THE REPROACH ANI CONDEMNATION OF THE SAID CORPORATIONS AFORE GOD)." I confess that I find it difficult to see how the present repreentatives of the Corporations wh $>$ perverted Gresham's trust are to escape from justly de erving the curse pronounced against those Corporations, unless they conscientiously take steps to restore Gresham's money to its proper uses. Let us hope that Gresham's curse may be realised in no more deadly form than that of an Act of Parliament repealing the former one which sanctioned the perversion of Gresham's money. Such a sequel to the Report of the Commission which has recently inquired into the proceedings of the Corpration and Companies of the City of London is not unlikely.

Whilst we should, I think, especially press upon public atten. tion the need for an institute of scientific rescarch in London, and indicate the source frum which its funds may be fitly derived, we must alio urge the found ation of other institutes in the provinces upon the scale already sketched, because it is only by the existence of numerous posts, and of a series of such posts-some of greater and some of less value, the latter more numerous than the former-that anything like a professional career for scientific workers can be constructed. It is especially necessary to consti. tute what I have termed "assistantships," that is, junior posts in which younger men assist and are trained by more experienced men. Even in the few institutions which do already exist additional provision of this kind is what is wanted more than anything else, so that there may be a progressive career open to the young student, and a sufficient field of trained investigators from which to select in filling up the vacancies in more valuable positions.

I am well aware that it will be said that the scheme which I have proposed to you is gigantic and almost alarming in respect of the amount of money which it demands. One hundred and sixty thousand pounds a year for biology alone must seem, not to my hearers, but to those who regard biology as an amusing speculation-that is to say, who know little or nothing about it -an extravagant suggestion. Unfortunately it is also true that such persons are very numerous-in fact, constitute an overwhelming majority of the community; but they are becoming less numerous every day. The time will come, it seems possible, when there will be more than one member of the Government who will understand and appreciate the value of scientific research. There are already a few members of the House of Commons who are fully alive to its significance and importance.

We may have to wait for the expenditure of such a sum as I have named, and possibly it may be derived ultimately from local rather than imperial sources, though I do not see why it should be; yet I think it is a good thing to realise nozo that this is what we ought to expend in order to be on a level with Germany. This apparently extravagant and unheard of anpropriation of public money is actually made every year in Germany.

I think it is well to put the matter before you in this definite manner, because I have reason to believe that even those whom we might expect to be well informed in regard to such matters, are not so, and as a consequence there is not that lieen sense of the inferiority and inadequacy of Engli:h arrangements in these matters $\mathrm{xhich}$ one would gladly see actuating the conduct of English statesmen. For ins'ance, only a few years ago, when spealing at Nottingham, the present Prime Minister, who has taken an active part in rearranging our universities, and has, it is well known, much intere $t$ in science and learning, stated that 27,000/., the capital sum expended on the Nottingham College of Science, was a very important contribution to the support of learning in this country, amounting, as he said he was able to state, from the perusal of official ducuments, to as much as one-1hird of what was spent in Germany during the past year upon her numerous universities, which were so of ten held up to England as an example of a well supported academical system. Now, I do not think that Mr. Gladstone can have ever had the opportunity of considering the actual facts with regard to German universities, for he was in this instance misled by the official return of expenditure on a single university, namely, that of Strasburg; the total annual expenditure on the twenty-one German unversities being, in reality, about $8 \mathrm{co}, 000 \mathrm{l}$, by the side of which a capital sum of $27,000 l$. looks very small indeed. 1 cannot but believe that if the facts were known to public men, in reference to the expenditure incurred by foreign States in support of scientific inquiry, they would be willing to do something in this country of a sufficient and statesmanlike character. As it is, the concessions which have been made in this direction appear to me to be in some instances not based upon a really comprehensive knowledge of the situation. Thus the tentative grant of $4,000 l$. a year from the Treasury to the Royal Society of London appears to me not to be a well-devised experiment in the promotion of scientific research by means of grants of money, because it is on too small a scale to produce any definite effect, and because the money cannot be rclied upon from year to year as a permanent source of support to any serious undertaking.

The Royal Society most laboriously and conscientiousily does its best to use this money to the satisfaction of the country, but the lask thus assigned to it is one of almost insurmountable difficulty. In fact, no such miniature experiments are needed. The experiment las been made on a large scale in Germany, and satisfactory re:ults have been obtained. The reasonable course to pursue is to benefit by the experience, as to details and methods of administration, obtained in the course of the last sixty years in Germany, and to apply that experience to our own case.

It is quite clear that "the voluntary principle" can do little towards the adequate endowment of scientific research. Ancient endow ments belonging to the country mu:t be applied thereto, or else local or imperial laxes must be the source of the necessary support. Seeing that the results of research are distinctly of imperial, and not of local value-it would seem appropriate 
that a portion of the imperial revenue should be devoted to their achievement. In fact, as I have before mentioned, the principle of such an application of public money has long been admitted, and is in operation.

Whilst voluntary donations on the part of private persons can do little to constitute a fund which shall provide the requisite endowment for the scheme of biological institutes which I have sketched (not to mention those required for other branches of science), yet those who are interested in the ,rogress of scientific investigation may by individual effort do something, however little, towards placing research in a more advantagcous position in this country. Supposing it were possible, as I am sanguine enough to believe that it is, to collect in the course of a year or two from private sources a sum of $20,000 \%$. for the maintenance of a biological laboratory and staff, it would be necessary, in expending so limited a sum, to aim at the provision of something which would be likely to produce the largest and most obvious results in return for the outlay, and to benefit the largest number of scientific observers in this department.

I believe that it is the general opinion among biologists that there could be no more generally useful institution thus set in operation than a biological laboratory upon the sea-coast, which, besides its own permanent staff of officers, would throw open its resources to such naturalists as might from time to time be able to devote themselves to researches within its precincts. There is no such laboratory on the whole of the long line of British coast. At Naples there is Dr. Dohrn's celebrated and invaluable laboratory, which is frequented by naturalists from all parts of the world; at Trieste the Austrian Government supports such a laboratory; at Concarneau, Roscoff, and Villefranche, the French Government has such institutions; at Beaufurt, in North Carolina, the Johns Hopkins University has its marine laboratory ; and at Newport, Professor Alexander Agassiz has arranged a very perfect institution also for the study of marine life. In spite of the great interest which Engli.h naturalists have always taken in the exploration of the sea and marine organisms--in spite of the fact that the succes; and even the existence of our fisheriesindustries to a large extent depends upon our gaining the knowledge which a well-organised laboratory of marine biology would help us to gain, there is actually no such institution in existence.

This is not the occasion on which to explain precisely how and to what extent a laboratory of marine zoslogy might be of national importance. I hope to see that matter brought before the Section during the course of our meeting. But I may point out now, that though it appears to me that the great need for biological institutes, to which I have drawn your attention, can not be met by private munificence, and must in the end be arranged for by the continued action of the Government in carrying out a policy to which it has for many years been committed, and which has been approved by Con ervatives and Liberals alike -yet such a special institution as a laboratory of marine biology, serving as a temporary workshop to any and all of our numerous students of the important problems connected with the life of marine plants and animals, might very well be undertaken from private funds. Should it be possible, on the occasion of this meeting of the British Association in Southport, to obtain sowe promise of assistance towards the realisation of this project, I think we shall be able to congratulate ourselves on having done something, though small perhaps in amount, towards making better provision for biological research, and therefore something towards the advancement of science.

In conclusion, let me say that, in advocating to-day the clain of biological science to a far greater measure of support than it receives at present from the public funds, I have endeavoured to press that claim chiefly on the ground of the obvious utility to the community of that kind of knowledge which is called biology. I have endeavoured to meet the opposition of those who object to the interference of the State wherever it may be possible to attain the end in view without such interference, but who 1 rofess themselves willing to see public money expended in promoting objects which are of real importance to the country, and which cannot be trusted to the voluntary enterprise arising from the operation of the laws of self-preservation and the struggle for wealth. There are, however, it seems to me, further reasons for desiring a thorough and practical recognition by the State of the value of scientific research. There are not wanting persons of some cultivation who have perceived and fully realised the value of that knowledge which is called science, and of its methods, and yet are anxious to restrain rather than to aid the grow th of that knowledge. They find in science something inimical to their own interests, and accordingly either condemn it as dangerous and untrustworthy, or encourage themselves to treat it with contempt by asserting that "after all, science counts for very little" -a statement which is unhappily true in one sense, though totally untrue when it is intended to signify that the progress $c$ f science is not a maiter which profoundly influences every factor in the well-being of the community. Amongst such people there is a positive hatred of science, wbich finds expression in their exclusion of it, even at this day, from the ordinary curriculum of public school education, and in the baseless though of t-repeated calumny that science is hostile to art, and is responsible for al that is harsh, ugly, and repulsive in modern life. To such opponents of the advancement of science, it is of little use to offer explanations and arguments. But we may, when we reflect on their instinctive hostility and the misrepresentations of science and the scientific spirit which it leats them to disseminate, console ourselves by bringing to mind what science really is, and what truly is the nature of that calling in which a man who makes new knowledge is engaged.

They mock at the botanist as a pedant, and the zoologist as a monomaniac; they execrate the physiologist as a monster of cruelty, and brand the geologist as a blasphemer; chemi-try is held responsible for the abomination of aniline dyes and the pollution of rivers, and physics for the dirt and misery of great factory towns. By these unbelievers science is declared responsible for individual eccentricities of character, as well as for the sins of the commercial utilisers of new knowledge. The pursuit of science is said to produce a dearth of imagination, incapability of enjoying the beauty either of nature or of art, scorn of literary culture, arrogance, irreverence, vanity, and the anbition of personal glorification.

Such are the charges from time to time made by those who dislike science, and for such reasons they would withhold, and persuade others to withhold, the fair measure of support for scientific research which this country owes to the community of civilised States. Not in reply to these misrepresentations, tut by way of contrast, I would nere state what science seems to be to those who are on the other side, and how, therefore, it : eems to them wrong to delay in doing all that the wealth and power of the State can do to promote its progress.

Science is not a name applicable to any one branch of knowledge, but includes all knowledge which is of a certain order or scale of completeness. All knowledge which is deep enough to torch the causes of things, is Science ; all inquiry into the causes of things is scientific inquiry. It is not only co-extensive with the area of human knowledge, but no branch of it can advance far withont reacting upon other branches; no defartment of Science can be neglected without sooner or later causing a check to other departments. No man can truly say this branch of Science is useful and shall be cultivated, whilst this is worthless and shall be let alone; for all are necessary, and one grows by the aid of another, and in turn furnishes methods and results assisting in the progress of that from which it lately borrowed.

We desire the increase and the support and the acceptance of Science, not only because it has a certain material value and enables men to battle with the forces of nature and to turn them to account, so as to increase both the intensity and the extension of healthy human life: that is a good reason, and for some persons, it may be, the only reason. But there is something to be said beyond this.

The pursuit of scientific discovery, the making of new know ledge, gratifies an appetite which, from whatever cause it may arise, is deeply seated in man's nature, and indeed is the most distinctive of his properties. Man owes this intense desire to know the nature of things, smothered though it of ten be by other cravings which he shares with the brutes, to an inherited race-perception stronger than the reasoning faculty of the individual. When once aroused and in a measure gratified, this desire becomes a guidirg passion. The instinctive tendency to search out the causes of things, gradually strengthening as generation after generation of men bave stumbled and struggled in ignorance, has at last become an active and widely extending force: it has given rice to a new faith.

To obey this instinct-that is, to aid in the production of new knowledge-is the keenest and the purest pleasure of $\mathrm{which}$ man is capable, greater than that derived from the exercise of his animal faculties, in proportion as man's mind is sowething greater and further developed than the mind of brutes. It is in itself an unmixer good, the one thing which commends itself as still "worth while" when all other employments and delights prove themselves stale and unprofitable.

Arrogant and foolish as those men have appeared who, in 
time, of persecution and in the midst of a contemptuou, soc ety, have, with an ardour proportioned to the prevailing neglect, pursued some special line of scientific inquiry, it is nevertheless true that in itself, apart from special social conditions, Science must develop in a community which honours and desires it before all things, qualities and characteristics which are the righest, the most human of human attributes. These are, firstly, the fearless love and unflinching acceptance of truth; hopeful patience; that true humility which is content not to know what cannot be known, yet labours and waits; love of Nature, who is not less, but more, worshipped by those who know her best; love of the human brotherbood for whom and with whom the growth of Science is desired and effected.

No one can trace the limits of Science, nor the possibilities of happiness both of mind and budy which ic may bring in the future to mankind. Boundless though the prospect is yet the minutest contribution to the onward growth has its absolute and unassailable value; once made it can never be lost; its effect is for ever in the history of man

Arts perish, and the noblest works which artists give to the world. Art (though the source of great and noble delights) cannot create nor perpetuate; it embodies only that which already exis $s$ in human experience, whil $t$ the results of its highest flights are doomed to decay and sterility. A vain regret, a constant effort to emulate or to imitate the past, is the fitting and laudable characteristic of Art at the present day. There is, indeed, no truth in the popular partition of human affairs between Science and Art as between two antagonistic or even comparable interests ; but the contrast which they present in points such as those just mentioned is forcible. Science is essentially creative; new knowledye-the experience and understanding of things which were previously non-existent for man's intelligence, is its constant acbievement. And these creations never perish; the new is built on and incorporates the old; there is no turning back to recover what has lapsed throush age; the oldest discovery is even fresher than the new, yielding in ever increasing number new results, in which it is itself reproduced and perpetuated, as the parent in the child.

Tnis, then, is the faith which has taken shape in proportion as the innate desire of man for more knowledge has asserted itself-namely, that there is no greater good than the iucrease of Science; that through it all other good will follow. Good as Science is in itself, the desire and search for it is even better, raising men above vile things and worthless competitions to a fuller life and keener enjoyments. Through it we believe that man will be saved from misery and degradation, not merely acquiring new material powers, but learning to use and to guide his life with understanding. Through Science he will be freed from the fetters of superstition; through faith in Science he will acquire a new and enduring delight in the exercise of his capacities; he will gain a zesi and interest in life such as the present phase of culture fails to supply.

In opposition to the view that the pursuit of Science can obtain a strong hold upon human life, it may be argued, that on no reasonable ground can it appear a nece-sary or advantageous thing to the individual man to concern himself with the growth and progress of that which is merely likely to benefit the distant posterity of the human race. Our reply is: Let those who contend for the reasonableness of human motives develop, if they can, any theory of suman conduct in which reasonable self-interest shall be man's guide. We do not contend for any such theory. By reasoning we may explain and trace the development of human nature, but we cannot change it by any such process. It is demonstrably unreasonable for the individual man, guided by self-interest, to share the dangers and privations of his brother-man, and yet, in common with many lower animals, he has an inherited quality which makes it a pleasure to him to do so ; it is unreasonable for the mother to protect her offspring, and yet it is the natural and inherited quality of mothers to derive pleasure from doing so; it is unreasonable for the half-starved poor to aid their wholly starving brethren, and yet such compassion is natural and pleasurable to those who show it, and is the constant rule of life. Unreasonable though these thing; are from the point of view of individual selfinterest, yet they are done because to do them is pleasurable, to leave them undone a pain. The race has, as it were, in these respects befooled the individual, and in the course of evolution has planted in him, in its own interests, an irrational capacity for taking pleasure in doing that which no reasoning in regard to self-interest could justify. As with these lower and more widely distributed in social animals, so is it with this higher and more peculiar instinct-the tendency to pursue new knowledge. Whether reasonable or not, it has by the laws of heredity and selection become part of us and exists : its operation is beneficial to the race: its gratification is a source of keen pleasure to the individual-an end in itself. We may safely count upon it as a factor in human nature; it is in our power to cultivate and develop it, or, on the other hand, to starve and distort it for a while, though to do so is to waste time in opposing the irresistible.

As day by day the old-faslioned stimulus to the higher life loses the dread control which it once exercised over the thoughts of men, the pursuit of wealth and the indulgence in fruitless gratifications of sense become to an increasing number the chief concerns of their mental life. Such occupations fail to satisfy the deep desires of humanity; they become wearisome and meaningless, so that we hear men questioning whether life be worth living. When the dreams and aspirations of the youthful world have lost their old significance and their strong power to raise men's lives, it will be well for that community which has or ranised in time a following of and a reverence for an ideal Good, which may serve to lift the national mind above the level of sensuality and to insure a belief in the hopefulness and worth of life. The faith in Science can fill this place-the progress of Science is an ideal Good, sufficient to exert this great influence.

It is for this reason more than any other, as it seems to those who hold this faith, that the progress and diffusion of scientific research, its encouragement and reverential nurture, should be a chief business of the community, whether collectively or individually, at the present day.

\section{Department of Anthropology}

Address by William Pengelly, F.R.S., F.G.S., VicePresident of the Section.

Anthropology, on ore of its numerous sides, marches with geol gy; and hence it is, no doubt, that I, for many years a labourer very near this somewhat ill-defined border, have been invited to assist my friends and neighbours in the work which lie; before them during the Association week. I have the more cheerfully accepted the invitation from a vivid recollection that, when on a few occasions I have come uninvited into this Department, my reception has been so very cordial as to lead me to ask myself whether the reports which for many years (I 864 to 1880 ) I laid annually before my geological brethren did not derive their chief interest from their anthropological bearings and teachings.

In 1858 - a quarter of a century ago-I had the pleasnre of reading to the Geological Section of the Association the first public communication on the exploration, then in progress, of Brixham Cavern (more correctly, Brixhaw Windmill Hill Cavern); and as any interest connected with that paper lay entirely in the evidence it contained of the inosculation and contemporaneity of human industrial relics, of a rude character, with remains of certain extinct mammals, I purpose on this occasion to lay before the Department a few thoughts, retrospective and prospective, which may be said to radiate from that exploration, confining $m$. self mainly to South Devon.

Probably nothing will better show the apparent apathy and scepticism with which, up to $185^{8}$, all geological evidence of the antiquity of man was received by British geologists generaliy, than the following statement of facts :-

About the beginning of the second quarter of the present century the late Rev. J. MacEnery made Kent's Cavern, or Kent's Hole, near Torquay, famous by bis researches and discoveries there. He not only found flint implements beneath a thick continuous sheet of stalagmite, but, after a most careful and painstaking investigation in the presence of witnesses, arrived at the conclusion that the flints "were deposited in their deep position before the creation of the stalagmite" (Trans. Devon. Assoc. iii. 330); and when it was suggested by the Rev. Dr. Buckland, to whom he at once and without reservation communicated all his discoveries, that "the ancient Britons had scooped out ovens in the stalagmite, and that through them the knives got admission to the "diluvium,"” he replied, "I am bold to say that in no instance have I discovered evidence of breaches or ovens in the floor, tut one continuous plate of stalagmite diffused uniformly over the loam" (Ilid. p. 334). 
He added, "It is painful to dissent from so high an authority, and more particularly so from my concurrence generally in his views of the phenomena of these caves, which three years' personal observation has in almost every instance enabled me to verify" (Ibid. p. 338).

It is, perhaps, not surprising that Dr. Buckland, one of the leading geolugists of his day, should be too tenacious of his opinion, and feel too secure in his position to yield to the statements and arguments of his comparatively young friend MacEnery, then scarcely known to the scientific world.

That the position taken by Buckland retarded the progress of truth, and was calculated to check the ardour of research, is apparently certain, and much to be regretted; but it should be remembered that, at least, as early as 1819 he taught that " the two great points ... of the low antiquity of the human race, and the universality of a recent deluge, are most satisfac orily confirmed by everything that has yet been brought to light by geological investigations" ("Vindiciæ Geologicæ," p. 24); that early in 1822 he reiterated and emphasised these opinions in his famous Kirkoale paper (Phil. Trans. for 1822, pp. 171-236), which the Royal Society "crowned with the Copley medal" (Quart. Fourn. Geol. Soc. vol. xiii. p. xxxiii.); that in 1823, having amplified and revised this paper, he published it as an independent quarto volume under the attractive title of "Reliquix Diluvianæ," of which he issued a second edition in 1824 ; and that, though his acquaintance with Kent's Cavern was much less intimate than that of MacEnery, he, nevertheless, was, of the two, the earlier worker there, and in fact had discovered a flint implement in it before MacEnery had ever seen that or any other cavern-the first tool of the kind found in any cavern, it is believed, and which in all probability was met with under circumstances not in conflict $x$ ith his published opinion on the low artiquity of man. I confess that under such circumstances, human nature being what it is, the line followed by Dr. Buckland seems to me to have been that which most men would have pursued.

It was, at any rate, the line to which he adhered as late, at least, as 1837 , tor in his well-known " Bridgewater Treatise," published that year, after describing his visit to the caverns near Liége, famous through the discoveries of Dr. Schmerling, he said, "The human bones found in these caverns are in a state of less decay than those of the extinct species of beasts; they are accompanied by rude flint knives and other instruments of flint and bone, and are probably derived from uncivilised tribes that inhabited the caves. Some of the human bones may also be the remains of individuals who, in more recent times, have been buried in such convenient repositories. M. Schmerling . . expresses his opinion that these human bones are coeval with those of the quadrupeds, of extinct species, found with them; an opinion from which the author, after a careful examination of M. Scbmerling's collection, entirely dissents" (op. cit. i. 602).

It may be doubted, however, whether his faith in these, his early, convictions remained unshaken to the end. I have frequently been told by one of his contemporary professors at Oxford, who knew him intimately, that Buckland shrank from the task of preparing for the press new editions of his " Reliquia Diluvianæ" and his "Bridgewater Treatise." "The work," he said, "would be not editing, but re-writing."

Mr. MacEnery intended to publish his "Cavern Researches" in one volume quarto, illustrated $\mathrm{w}$ ith thirty plates. In what appears to have been his second prospectus, unfortunately not dated, he said, "The liwited circulation of works of this nature, being by no means equal to the expenses attendant on the execution of so large a series" [of plates], "the author is obliged to depart from his original plan, and to solicit the support of those who may feel an interest in the result of his researches."

There is reason to believe that at least twenty-one of the piates were ready, and that the rough copy of much of himanuscript was written; but that, the support he solicited not being forthcoming, the idea of publishing had to be abandoned (see Trans. Devon. Assoc. iii. 198-201).

In 1840 Mr. R. A. C. Austen (now Godwin-Austen), F.G. S., read to the Geological Society of London a paper on the Bone Caves of Devonshire, which, with some amplifications, was incorporated in his memoir on the geology of the south-east of Devonshire, printed in the Transactions of the Society in 1842 (2nd ser. vi. 433-489). Speaking of his own researches in Kent's Cavern he said, "Human remains and works of art, such as arrow-heads and knives of flint, occur in all parts of the cave and throughout the entire thickness of the clay: and no distinction founded on condition, distribution, or relative posi- tion can be observed whereby the human can be separated from the other reliquire" (Ibid. p. 444).

$\mathrm{He}$ added, "My own researches were constantly conducted in parts of the cave which had never heen disturbed, and in every instance the bones were procured from beneath a thick covering of stalagmite ; so far, then, the bones and works of man must have been introduced into the cave before the flooring of stalagmite had been formed" (Ibid. p. 446).

Though these important and emphatic statements were so fortunate as to be committed to the safe keeping of print with but little delay, and under the most favourable circumstances, they appear neither to bave excited any interest, nor indeed to have received much, if any, attention.

In 1846 , the Torquay Natural History Society appointed a Committee, consisting of Dr. Battersby, Mr. Vivian, and myself -all tolerably familiar with the statements of Mr. MacEnery and Mr. Austen - to make a few diggings in Kent's Cavern for the purpose of obtaining specimens for their mueum. The work, though more or less desultory and unsystematic, was by no means carelessly done, and the Committee were unanimously and perfectly satisfied that the objects they met with had been deposited at the same time as the matrix in which they were irhumed. At the close of their investigation they drew up a report which was printed in the Torquay Directory for November 6, 1846 (see Trans. Devon. Assoc. x. I62). Its substance, embodied in a paper by Mr. Vivian, was read to the Geological Society of London on May 12,1847 , as well as to the British Association in the succeeding June, and the following abstract was printed in the Report of the Association for that year (p. 73) :- -

The important point that we have established is, that relics of human art are found beneath the unbroken floor of stalagmite. After taking every precaution, by sweeping the surface, and examining most minutely whether there were any traces of the floor having been previously disturbed, we broke through the solid stalagmite in three different parts of the cavern, and in each instance found flint knives. .. . . In the spot where the most highly finished specimen was found, the passage was s? low that it was extremely difficult, with quarrymen's tools and good workmen, to break through the crust ; and the supposition that it had been previously disturbed is impossible."

It will be borne in mind that the same paper was read the month before to the Geological Society. The Council of that body, being apparently unprepared to print in their Quarterly Fournal the statements it contained, contented themselves with the following notice, given here in its entirety (op. cit. iii. 353):- -

"On Kent's Cavern, near Torquay," by Mr. Edward Vivian. "In this paper an account was given of some recent researches in that cavern by a committee of the Torquay Natural History Society, during which the bones of various extinct species of animals were found in several situations."

It will be observed that the "flint knives" were utterly ignored, a fact rendered the more significant by the following announcement on the wrapper of the journal :- "The Editor of the Quarterly fournal is directed to make it known to the public that the authors alone are responsible for the facts and opinions contained in their respective papers."

Such, briefly, were the principal researches in Kent's Cavern, at intervals from 1825 to 1847 . Their reception was by no means encouraging: Mr. MacEnery, after incurring very considerable expense, was under the necessity of abandoning the intention of publishing his "Cavern Researches ; "Mr. Austen's paper, though printed unabridged, was given to an apathetic, unbelieving world, and was apparently without effect; and $\mathrm{Mr}$. Vivian's paper, virtually the report by a committee of which he was a member, was cut down to four lines of a harmless, unexciting character.

For some years nothing occurred to break the quietude, which but for an unexpected discovery on the southern shore of Torbay would probably have remained to this day.

Early in $185^{8}$ the workmen engaged in a limestone quarry on Windmill Hill, overhanging the fishing town of Brixham in South Devon, broke unexpectedly a hole through what proved to be the roof of an unknown and unsuspected cavern. I visited it very soon after the discovery, and secured to myself the refusal of a lease to include the right of exploration. As the story of this cavern has been told at some length elsewhere (see Phil. Trans. clxiii. 471-572; or Trans. Devon. Assoc. vi. $775-856)$. it wili here suffice to say that at the instance of the late Ir. H. Falconer, the eminent palæontologist, the subject 
was taken up very cordially by the Royal and Geological Societies of London, a Committee was appointed by the latter hody, the exploration was placed under the superintendence of Mr. (nวw Prof.) Prestwich and myself, and, being the only resident member of the Committee, the actual superintendence fell of necessity to me.

The following facts connected with this cavern were no doubt influential in leading to the decision to have it explored :-

r. It was a virgin cave which had been hermetically sealed during an incalculably long period, the last previous event in its history being the introduction of a reinde $2 r$ antler, found attached to the upper surface of the stalagmitic floor. It was therefore free from the objection urged sometimes against Kent's Cavern, that, having been known from time immemorial, and up to 1825 always open to all comers, it had perhaps been ransacked again and again.

2. It was believed, and it proved, to be a comparatively very small cavern, so that its complete exploration was not likely to require a large expenditure of time or of money.

It will be seen that the exploration was placed under circumstances much more likely to command attention than any of those which had preceded it. It was to be carried on under the auspices of the Royal and Geological Societies, by a Comruittee consisting of Mr. S. H. Beckles, Mr. G. Busk, Rev. R. Everest, Dr. H. Falconer, Mr. Godwin-Austen, Sir C. Lyell, Prof. Owen, Dr. J. Perey, Mr. J. Prestwich, Prof. (now Sir A. C.) Ramsay, and myself-all Fellows of the Geological Society, and almost all of them of the Royal Society also.

It was impossible not to feel, however, that the mode of exploration must be such as would not merely satisfy those actually engaged in the work, but such as would command for the results which might be obtained the acceptance of the scientific world generally. Hence I resolved to have nothing whatever to do with "trial pits" here and there, or with shafis to be sunk in selected places ; but, first, to examine and remove the stalagmite floor; then the entire bed immediately below (if not of inconvenient depth) horizontally throughout the entire length of the cavern, or so far as practicable; this accomplished, to proceed in like manner with the next lower bed; and so on until all the deposits had been removed.

This method, uniformly followed, was preferable to any other, because it would reveal the general stratigraphical order of the deposits, with the amount and direction of such "dip" as they might have, as well as any variations in the thickness of the beds; it would afford the only chance of securing all the fossils, and of thus ascertaining, not only the different kinds of animals represented in the cave, but also the ratios which the numbers of individuals of the various species bore to one another, as well as all peculiar or noteworthy collocations; it would disclose the extent, character, and general features of the cavern itself; it was undoubtedly the least expensive mode of exploration; and it would render it almost impossible to refer bones or indications of human existence to wrong beds, depths, or associations.

The work was begun in July, 1858 , and closed at the end of twelve months, when the cavern had practically been completely emptied; an official report was printed in the Philosophical Transactions for 1873 , and all the specimens have been handed over to the British Museum.

The paper on the subject mentioned at the beginning of this address was read in September, $185^{8}$, during the meeting of the Association at Leeds, when I had the pleasure of stating that eight flint tools had already been found in various parts of the cavern, all of them inosculating with bones of mammalia, at depths varying from nine to forty-tivo inches in the cave-earth, on which lay a sheet of stalagmite from three to eivht inches thick, and having within it and on it relics of lion, hyæna, bear, mammoth, rhinoceros, and reindeer.

It soon became obvious that the geological apathy previously spoken of had been rather apparent than real. In fact, geologists were found to have been not so much disinclined to entertain the question of human antiquity as to doubt the trustworthi. ness of the evidence which had previously been offered to them on the subject. It was felt, moresver, that the Brixham evidence made it worth while, and indeed a duty, to re-examine that from Kent's Cavern, as well as that said to have been met with in river deposits in the valley of the Somme and elsewhere.

The first fruits, I believe, of this awakening was a paper by Mr. Prestwich, read to the Royal Society, May 26, 1859, on the occurrence of flint implements, associated with the remains of animals of extinct species in beds of a late geological period, in France at Amiens and Abbeville, and in England at Hoxne (Phil. Trans, for 1860, pp. 277-317). This paper contains explicit evidence that Brixham Cayern had had no small share in disposing its author to undertake the investigation, which added to his own great reputation and rescued M. Boucher de Perthes from undeserved neglect. "It was not," says Mr. Prestwich, " until I had myself witnessed the conditions under which these flint implements had been found at Brixham, that I became fully impressed with the validity of the doubts thrown upon the previously prevailing opinions with respect to such remains in caves" (op. ci . p. 280).

Sir C. Lyell, too, in his address to the Geological Section of the British Association, at Aberdeen, in September, 1859, said, "The facts recently brought to light during the systematic investigation, as reported on by Dr. Falconer, of the Brixham Cave, must, I think, have prepared you to admit that scepticism in regard to the cave evidence in favour of the antiquity of man had previously been pushed to an extreme" (Report Brit. Assoc. I859, Trans. Sects. p. 93).

It is probably unnecessary to quote further to show how very large a share the exploration at Brixham had in impressing the scientific world generally with the value and importance of the geological evidence of man's antiquity. That impression, begun as we have seen in 1858 , has not only lasted to the present day, but has probably not yet culminated. It has produced numerous volu nes, crowds of papers, countless articles in reviews and magazines, in various countries; and, perhaps in order to show how very popular the subject became almost immediately, it is only necessary to state that Sir C. Lyell's great work on the "Antiquity of Man" was published in February, 1863; the second edition appeared in the following April, and the third followed in the succeeding November-three editions of a bulky scientific work in less than ten months! A fourth edition was published in May, 1873 .

Few, it may be presumed, can now doubt that those who before 1858 believed that our fathers had under-estimated human antiquity, and fonght for their belief, have at length obtained a victory. Nevertheless, every anthropologist has doubtless from time to time

\section{"Heard the distant and random gun
That the foe was sullenly firing."}

The "foe," to speak metaphorically, seems to consist of very irregular forces, occasionally unfair but never dangerous, sometimes very amusing, and frequently but badly armed or without any real arinour. The Spartan law which fined a citizen heavily for going into battle unarmed was probably a very wise one.

For example, and dropping a metaphor, a pamphlet published in I877 contains the following passage:- "With regard to all these suppo ed flint implements and spear-and arrow-heads found in various places, it may be well to mention here the frank confession of Dr. Carpenter. He has told us from the presidential chair of the Royal Academy that 'No logical proof can be adduced that the peculiar shapes of these flints were given them by human hands" "(see "Is the Book Wrong? A Question for Sceptics,' by Hely H. A. Smith, p. 26). The words ascribed to Dr. Carpenter are put within inverted commas, and are the whole of the quotation from him. I was a good deal mystified on first reading them, for while it seemed likely that the president spoken of was the well known member of this Association -Dr. W. B. Carpenter-it was difficult to account for his being in the presidential chair of the Royal Academy, and not easy to understand what the Royal Academy had to do with fint implements. A little search, however, showed that the address which Dr. W. B. Carpenter delivered in 1872 from the presidential chair of, not the Royal Academy, but the British Association, contained the actual words quoted, followed immediately by others which the author of the pamphlet found it inconvenient to include in his quotation. Dr. Carpenter, speaking of "common sense," referred, by way of illu-tiation, to the "flint implements" of the Abbeville and Amiens gravel beds, and remarked, "No logical proof can be adduced that the peculiar shapes of these flints were given to them by human hands; but does any unprejudiced person now doubt it?" (Report Brit. Assoc. 1872, p. Ixxv.). Dr. Carpenter, after some further remarks on the "flint implements," concluded his paragraph respecting then with the following words :- "Thus what was in the first instance a matter of discussion, has now become one of those 'self-evident' pro positions which claim the unhesitating assent of all whose opinion on the subject is entitled to the least weight."

It cannot be doubted that, taken in its entirety, that is to say, taken as every lover of truth and fairness should and would take 
it, Dr. Carpenter's paragraph would produce on the mind of the reader a very different effect to that likely, and no doubt intended, to be produced by the mutilated version of it given in the pamphlet.

A second edition of the pamphlet has been given to the world. Dr. Carpenter is still in the presidential chair of the Royal Academy, and the quotation from his address is as conveniently short as before.

It would be easy to bring together a large number of similar modes of "defending the cause of truth"-to use the words of the pamphlet just noticed--but space and time forbid.

I cannot, however, forego the pleasure of introducing the following recent and probably novel explanation of cavern phenomena. In I 882 my attention was directed to two articles, by one and the same writer, on "Bone-Cave Phenomena." The writer's theme was professedly the Victoria Cave, near Settle, Yorkshire, which he says was an old Roman lead mine, but his remarks are intended to apply to bone-caves in general. $\mathrm{He}$ takes a very eariy opportunity in the second article of stating that "We shall have to take care to distinguish between what is truly indicated in the 'science' view from what are purely imaginary exaggerations of its natural and bistorical phenomena" ; and he no doubt believes that he has taken this care.

"We have now," he says, "to present our own view of the Victoria Cave and the phenomena connected with it, premising that a great many of the old mines in Europe were opened by Phœnician colonists and metal w orkers, a thousand years before the Romans had set foot in Britain, which accounts for the various floors of stalagmite found in most caves, and al o for the variety of groups of bones embecided in them. The animals represented by them when living were not running wild about the hills devouring each other, as science men suppose, but the useful auxiliaries and trained drudges of the miners in their work. Some of them, as the bear, had simply been hunted and used for food, and others of a fierce character, as the hyæna, to frighten and keep in awe the native Britons. The larger species of mammalia, as the elephant, the rhinoceros and hippopotamus, and beasts foreign to the country, the Romans, no less than the Phonicians, had every facility in bringing with them in their ships of commerce from Carthage, or other of the African ports. These, with the native horse, ox, and stag, which are always found in larger numbers in the caves than the remains of foreign animals, all worked peacefully together in the various operations of the mines. . . T The hippopotamus, alth ung amphitious, is a grand beast for heavy work, such as mining, quarrying, or road-making, and his keeper would take care that he was comfortably lodged in a tank of water during the night. . . . The phenomena of the Victoria Cave Lead Mine differ in no material respect from tbose of tsun ireds of others, whether of lead, copper, silver, or iron, "orked in Roman and pre-Roman times in all parts of Europe. Its tunnels have all been regularly quarried and mined, not by ancient seas, but by the hands of his oric man. Double openings have been made in every case for convenient ingress and eyress, during the process of excavation. Its roadways had been levelled, and holes made up with breccia, gravel, sand, and bones of beasts that had succumbed to toil, on which sledges, trolleys, amd uaggons could glide or run. . . . Near the entrance inside Victoria Cave were found the usual beds of charcoal and the heartis for refining the metal, while close by on the hillside may still be seen the old kilns in which the men 'roasted' the metallic ores and burned lime."

Should any one be disposed to ascribe these articles to some master of the art of joking, it need only be replied that they appeared in a religious journal (The Champion of the Faith against Current Infidelity for April 20, and May 11, 1882, vol. i. pp. 5 and 26), with the writer's name appended; and that I have reason to believe they were written seriously and in earnest.

It has been already intimated that Brixham Cavern has secured a somewhat prominent place in literature; and it can : carcely be needful to add that some of the printed statements respecting it are not quite correct. The following instances of inaccuracy may be taken as samples :-

The late Prof. Ansted, describing Brixham Cavern in 1861, said, "In the middle of the cavern, under stalagmite itself, and actually entangled with an antler of a reindeer and the bones of the great cavern bear, were found rude sculptured flint:, such as are known to have been used by savages in most parts of the world" ("Geolo sical Gossip," p. 209).

To be "entangled" with one another, the antler, the bones of the cave bear, and the flints must have been all lying together
As a matter of fact, however, the antler was on the upper surface of the sheet of stalagmite, while all the relics of the cave bear and all the flints were in detrital beds below that sheet. Again, the flints nearest the bear's bones in question were two in number; they were twelve feet south of the bones, and fifteen inches less deep in the bed. There was no approach to entanglement.

Should it be suggested that it is scarcely necessary to correct errors on scientific questions in works, like "Geolngical Gossip," professedly popular and intended for the million, I should venture to express the opinion that the strictest accuracy is specially required in such books, as the great majority of their readers are entirely at the mercy of the compilers. Those who read scientific books of a higher class are much more capable of taking care of themselves.

Prof. Ansted's slip found its way into a scientific journal, where it was made the basis of a speculation (see Geologist, $\mathbf{1 8 6 1}$, p. 246$)$.

The most recent notewortby inaccuracies connected with thi famous cavern are, so far as I aw aware, two in the Engli.h edition of Prof. N. Joly's "Man before Metals" (1 883 ).

According to the first, "An entire left hind leg of Ursus spelirus was found lying above the incrustation of stalagmite which covered the bones of other extinct species and the carved flints" (p. 52).

It is ouly necessary in reply to this to repeat what has been already stated: all the bones of cave-bear found in the cavern were in beds belou the stalagmite.

The following quotation from the sane work contains the second inaccuracy, or, more correctly, group of inaccuracies, mentioned above: "We may mention among others the crve at Brixham, where, associated with fragments of rude pottery and bones of extinct species, heaps of oyster shells and other salt"ater mollusks occur, as well as fish-bones of the genus scarus" (p. 104).

I am afraid there is no way of dealing with this para raph except that of meeting all its statements with unqualified denials. In short, Brixham Windmill IIill Cavern contained no pottery of any kind whatever, not a single oyster-shell, nor even a solitary bone of any species of fish. One cormon limpet sbell was the only relic of a marine organism met with in the caveri.

As already intimated, the result of the researches at Brixham quickened a de-ire to re-examine the Kent's Cavern evidence, and this received a considerable stimulus from the publication of Sir C. Lyell's "Antiquity of Man" in 1863. Having in the meantime made a careful survey of the cavern, and ascertained that there was a very large area in which the deposits "ere certainly intact, to say nothing of unsuspected branches which in all probability would be discovered during a thorough and systemat $\mathrm{c}$ exploration, I had arrived at the conclusion that, tahing the cavern at its known dimensions merely, the cost of an investigation as complete as that at Brixham would not be less than $1000 \%$.

Early in 1864 I suggested to Sir C. Lyell that an application should be made to the British Association, during the meeting to be held at Bath that year, for the aspnintment of a Comnittee, with a grant of money, to make an exploration of Kent's Cavern; and it was decided that I should take the necessary steps in the matter. The proposal being cordially received by the Committee of the Geslogical Section, and well supported in the Committee of Recommendations, a Commitee-consisting of Sir C. I.yell, Mr. J. Evan;, Mr. (now Sir) J. Lubbock, Prof. J. Phillips, Mr. E. Vivian, and myself (Hon. Secretary and Reporter) - was appointed, with rool. placed at thi ir disposal. Mr. G. Busk was added to the Committee in I866, Mr. W. Boyd Dawlins in I868, Mr. W. Ayshford Sanford in 1869, and Mr. J. E. Lee in 1873. The Jate Sir L. Palk (afterwards Lord Haldon), the proprietor, placed the cavern entirely under the control of the Committee during the continuance of the work; the investigation was be un on March 28, 1865 , and continued without intermision to June 19,1880 , the Committee heing annually reap. pointed with fresh grants of money, which in the aggregrate amounted to $1900 \%$, , lesides $63 \%$. received from various private sources.

The mode of exploration was essentially the same as that followed at Windmill Hill, Brixham, but as Kent's Cavern, instead of being a series of narrow galleries, contained a considerable number of capacious chambers, and as the aim of the explorers was to ascertain not merely what cbjects the deposits contained, but their exact position, their distribution, their condition, their collocation, and their relative abundance, the detail s had to be 
considerably more elaborate, while they remained so perfectly simple that the workmen had not the least difficulty in carrying them out under my daily superintendence. The process being fully described in the First Annual Report by the Committee (see Report. Brit. Assoc. 1865, pp. 19, 20), it is unnecessary to repeat it here.

Mr. Godwin-Austen, while agreeing with Mr. MacEnery that flint implements occurred under the stalagmite, contended that they were found throu shout the entire thickness of the cave earth. MacEnery, on the other hand, was of opinion that in most cases their situation was intermediate between the bottom of the stalagmite and the upper surface of the cave earth; and, while admitting that occasionally, though rarely, they had been met with somewhat lower, he stated that the greatest depth to which he had been able to trace them was not more than a few inches below the surface of the cave earth (Trans. Devon. Assoc. iii. 326-327). The Committee soon found themselves in a position to confirm Mr. Godwin-Austen's statement, and to say with him that "no distinction founded on condition, distribution, or relative position can be observed whereby the human can be separated from the other reliquir" (Trans. Geol. Soc. 2nd ser. vi. 444)

Mr. MacEnery's "Plate F" contains seven figures of three remarkable canine teeth, and the following statement respectin them :- "Teeth of Ursus cultridins, found in the cave of Kent's Hole, near Torquay, Devon, by Rev. Mr. McEnery, Jannary, I826, in Diluvial Mud mix'd with Teeth and Gnaw'd Bones of Rhinoceros, Ele phant, Horse, Ox, Elk, and Deer, with Teeth and Bones of Hyænas, Bears, Wolves, Foxes, \&c."

It is worthy of note that no other plate in the entire series names the date on which the specimens were found, or the mammals with whose remains they were commingled. This arose probably from the fact, well known to MacEnery, that no such specimeus had been found elsewhere in Britain; and possibly also to emphasise the statements in his text, should any doubt be throw $n$ on his discovery.

It is, no doubt, unnecessary to say here that the teeth belonged to a large species of carnivore to which, in 1846 , Prof. Owen gave the name of Machairodus latidens. MacEnery state; that the total number of teeth he found were five upper canires and one incisor, and the six museums in which they are now lodged are well known.

A considerable amount of scepticism existed for many years in some minds as to whether the relics just mentioned were really found in Kent's Cavern, it bein $y$ contended that from its zoological affinities Machairodus latidens must have belonged to an earlier fauna than that represented by the ordinary cave mammals; ant various hypotheses were invented to explain away the difficulty, most of them, at least, being more ingenious than ingenuous. Be this as it may, it was naturally hoped that the re-exploration of the cavern would set the question at rest for ever ; and it was not without a feeling of disappointment that I had to write seven successive annual reports without heing able to announce the discovery of a single relic of Machairodus. Indeed, the greater part of the Eighth Report was written with no better prospect; when, while engaged in washing a "find" met with on July 29,1872 , I found that it consisted of a well-marked incisor of Machairodus latidens, with a left ramus of lower jaw of bear, in which was one molar tooth. They were lying together in the first or uppermost footlevel of cave earth, having over it a continuous sheet of granular stalagmite $2 \cdot 5$ feet thick. There was no longer any doubt of MacEnery's accuracy; no doubt that Maciairodus latidens was a member of the cave earth fauna, whatever the zoological affinities might say to the contrary; nor was there any doubt that man and Machairodus were contemporaries in Devonshit.

I cannot pass from this case without directing attention to its bearing on negative evidence: had the exploration ceased on July 28, I 872 -the day before the discovery-those who had always declined to believe that Machairodus had ever been found in the cavern would have been able to urge, as an additional and apparently conclusive argument, that the consecutive, systematic, and careful daily labour of seven years and four months had failed to show that their scepticism was unwarranted. Nay, more, had the incisor been overlooked-and, being but a small object, this might very easily have occurred-they might finally have said " 15.25 years' labour"; for, so far as is known, no other relic of the species was met with during the entire investigation. In all probability had either of these by no means improbable hypotheses occurred, geologists and palæontoligists generally wculd have joined the sceptics; MacEnery's reputation would have been held in very light esteem; and-to say the least--his researches regarded with suspicion.

When their exploration began, and for some time after, the Committee had no reason to believe or to suspect that the cavern contained anything older than the cave earth; but at the end of five months, facts, pointing apparently to earlier deposits, began to present themselves; and, at intervals more or less protracted, additional phenomena, requiring apparently the same interpretation, were observed and recorded ; but it was not until the end of three full years that a vertical section was cut, showing, in undisturbed and clear succession, not only the cave earth with the granular stalagmite lying on it, but, under and supporting the cave earth, another, thicker, and continuous sheet of stalagmite - appropriately termed crystalline, and below this again an older detrital accumulation, known as the breccia, made up of materials utterly unlike those of the cave earth.

The breccia was just as rich a; the cave earth in osseous remains ; but the lists of species represented by the two deposits were very different. It will be sufficient to state here that, while remains of the hyæna prevailed numerically very far above those of any other mammal in the cave earth, and while his presence there was also attested by his teeth-marks on a vast number of bones, by lower jaws-including those of his own kith and kin --of which he had eaten off the lower borders as well as the condyles, by long bones broken obliquely just as hyænas of the present day break them, and by surprising quantities of his coprolites, there was not a single indication of any kind of his presence in the breccia, where the crowd of bones and teeth belonged almost entirely to bears.

No trace of the existence of man was found in the breccia until March, 1869, that is about twelve months after the discovery of the depoit itself, when a flint flake was met with in the third foot-level, and was believed to be not only a tool, but to bear evidence of having been used as such (see Report Brit. Assoc. 1869, pp. 201, 202). Two massive flint implements were discovered in the same deposit in May, 1872 , and at various subsequent times other tools were found, until at the close of the exploration the breccia had yielded upwards of seventy implements of flint and chert.

While all the stone tools of both the cave earth and the breccia were Palæolithic and were found inosculating with remains of extinct mammals, a mere in:pection shows that they belong to two distinct categories. Those found in the brecciathat is, the more ancient series-were formed by chipping a flint nodule or pebble into a tool, while those from the cave earththe less ancient series-were fashioned by first detaching a suitable flake from the nodule or pebble, and then trimming the flake $-n$ st the nodule-into a tool.

It must be unnecessary to say that the making of nodule tools necessitated the production of flakes and chips, some of which were no doubt utilised. Such flakes, however, must be reyarded as accidents, and not the final objects the workers had in view.

It is worthy of remark that in one part of the cavern, upwards of 130 feet in length, the excavation was carried to a depth of nine feet, instead of the usual four feet, below the bottom of the stalagmite ; and that, while no bone of any kind occurred in the breccia below the seventh foot-level, three fine flint nodule tools were found in the eighth, and several flint chips in the ninth, or lowest foot-level.

It may be added that the same fact presented itself in the lowest or corresponding bed in Brixham Windmill Hill Cavern. In short, in each of the two famous Devonshire caverns, the archæological zone reached a lower level than the palæontological.

That the breccia is of higher antiquity than the cave earth is proved by the unquestionable evidence of clear undisturbed superposition ; that they represent two distinct chapters and eras in the cavern history is shown by the decided dissimilarity of the materials composin $y$ them, the marked difference in the osseous remains they contained, and the strongly contrasted characters of the stone implements they yielded; and that they were separated by a wide interval of time may be safely inferred from the thickness of the bed of stalagmite between them.

It is probable, however, that the fact most significant of time and physical change is the presence of the hyæna in the cave earth or less ancient, but not in the breccia or mure ancient, of the two deposits. I called attention to this fact in a paper read to this Department ten years ago (see Report Brit. Assoc. 1873, pp. 209-214), and at greater length elsewhere in I875 (see Trans. Plym. Inst. v. 360-375). Bearing in mind the cave-haurits.ng 
habits of the hyæna, the great preponderance of his remains in the cave earth, and their absence in the breccia, it seems impossible to avoid the conclusion that he was not an occupant of Britain during the earlier period.

The acceptance of this conclusion, however, necessitates the belief ( $\mathrm{I}$ ) that man was resident in Britain long before the hyæna was.

(2) That it was possible for the hyæna to reach Britain between the deposition of the breccia and the deposition of the cave earth. In other words, that Britain was a part of the Continent during this interval.

Sir C. Lyell, it will be remembered, recognised the following geograpbical changes within the British area between the Newer Pliocene and historical times (see "Antiquity of Man," edition I873, pp. 33I, 332).

Firstly, a pre-Glacial Continental period, towards the close of which the Forest of Cromer flourished, and the climate was $s$ smewhat milder than at present.

Secondly, a period of submergence, when the land north of the $1 \mathrm{hames}$ and Bristol Channel, and that of Ireland, was reduced to an archipelago. This was a part of the Glacial age, and icebergs floated in our waters.

Thirdly, a second Continental period, when there were glaciers in the higher mountains of Scotland and Wales.

Fourtbly, the breaking up of the land through submergence, and a gradual change of temperature, resulting in the present geographical and climatal conditions.

It is obvious that if, as I venture to think, the Kent's Cavern breccia was deposited during the first Continental period, the list of mammalian remains found in it should not clash with the list of such remains from the Forest of Cromer, which, as we have just seen, flourished at that time. I called attention to these lists in I874, pointing out that according to Prof. Boyd Dawkins ("Cave-Hunting," p. 418) the forest bed had at that time yielded twenty-six species of mammals, sixteen of them being extinct, and ten recent; that both the breccia and the forest bed had yielded remains of the cave-bear, but that in neither of them had ary relic or trace of hyæna been found. A monograph on the "Vertebrata of the Forest Bed Series" was publi-hed in I882 by Mr. E. T. Newton, F.G.S., who, including many additional species found sc mewhat recently, but eliminating all those about which there was any uncertainty, said: "We still have forty nine species left, of which thirty are still living, and nineteen are extinct" (p. 135). Though the number of the species has thus been almost doubled, and the presence of the cave-bear remains undoubted, it continues to be the fact that no trace of the hyæna has been found in the forest bed, and no suspicion exists as to his probable presence amongst the eliminated uncertain species.

It should be added that no relic or indication of hyæna was met with in the "Fourth Bed" of Brixham Windmill Hill Cavern, believed to be the equivalent of the Kent's Hole breccia.

I am not unmindful of the fact that my evidence is negative only, and that raising a structure on it may be building on a sandy foundation. Nevertheless, it appears to me, as it did ten years ago, strong enough to bear the following inferences :-

I. That the hyæna did not reach Britain until its last Continental period.

2. That the men who made the Palrolithic nodule-tools found in the oldest known deposit in Kent's Cavern arrived during the Irevious great submergence, or, what is more probable-indeed, what alone seems possible unless they were navigators-during the first Continental period. In short, I have little or no doub that the earliest Devonians we have sighted were either of Glacial, or, more probably, of pre-Glacial age.

It cannot be necessary to add that while the discovery of remains of hyrena in the forest bed of Cromer, or any other contemporary deposit, would be utterly fatal to my argument, it would leave intact all other evidence in support of the doctrine of British Glacial or pre-Glacial man.

Some of my friends accepted the foregoing inferences in 1873 , while others, whose judgment I value, declined them. Since that date no adverse fact or thought has presented itself to me ; but through the researches and di coveries of others in comparatively distant parts of our island, and especially in East Anglia, the belief in Briti:h rre-Glacial man appears to have risen above the stage of ridicule, and to have a decided prospect of general scientific acceptance at no distant time.

I must, before closing, devote a few words to a class of workers who are "more plague than profit."
The exuberant enthusiasm of some would-be pioneers in the question of human antiquity results occasionally in supposed "discoveries" having an amusing side; and not unfrequently some of the pioneers, though utter strangers, are so good as to send me descriptions of their "finds," and of their views respecting them. The following case may be taken as a sample:In 1881 , a gentleman, of whom I had never heard, wrote, stating that he was one of those who felt deeply interested in the antiquity of man, and that he had read all the books he could command on the subject. He was aware that it had been said by one palæontologist to be "unreasonable to suppose that man had lived during the Eocene and Miocene periods," but he had an indistinct recollection that another eminent man had somewhere said that "man had probably existed in England during a tropical Carboniferous flora and fauna." He then went on to say, "I have got that which I cannot but look upon as a fossil human skull. I have endeavoured to examine it from every conceivable standpoint, and it seems to stand the test. The angles seem perfect, the contour the same but smaller in size than the average human head; but that, in my opinion, is only what should be expected if we assume that man lived during the Carhoniferous period, in spite of what Herodotus says about the body of Orestes." Finally, he requested to be allowed to send me the specimen. On its arrival it proved, of course, to be merely a stone; and nothing but a strong " unscientific use of the imagination" could lead any one to believe that it had ever been a skull, human or infrahuman.

It may be added that a few years ago a gentleman brought me what he called, and believed to be, "three human skulls and as many elephants' teeth," found from time to time, during his researches in a limestone quarry. They proved to be nothing more than six oddly shaped lumps of Devonian limestone.

So far as Britain is concerned, cave-hunting is a science of Devonshire birth. The limestone caverns of Oreston, near Plymouth, were examined with some care in the interests of palæontology as early as 1816 , and subsequently as they were successively discovered. The two most famous caverns of the same county-one on the northern, the other on the southern shore of Torbay-have been anthropological as well as palæontological studies; and, as we have seen, have had the lion's share in enlarging our estimate of human antiquity. The researches have, no doubt, absorbed a great amount of time and of labour, and demanded the exercise of much care and patience; but they have been replete with interest of a high order, which would be greatly enhanced if I could feel sure that your time has not been wasted nor your patience exhausted in listening to this address respecting them.

\section{JOSEPH-ANTOINE-FERDINAND PLATEAU.}

$\mathrm{THE}$ career of this indefatigable investigator, as we announced last week, has just closed. Born in the second year of the present century, he has occupied a notable position in the scientific world for more than fifty years. Before he reached middle age he met with the terrible misfortune of losing his eyesight while trying venturesome experiments on the physiological effects of light. His scientific career seems to have become only more active in consequence! When we think of the ease and success with which certain chessplayers can, blind-fold, carry on some dozen or two simultaneous games, there seems little to surprise us in the mathematical career of Euler after he became blind. But the difficulties which stood in the way of the physicist, and which he successfully overcame, were of a far more formidable character. Had his chief investigations related to sound, the loss of eyesight might have but little interfered with them. But to carry out by the help of others' eyes a long series of investigations connected with Physiological Optics was a triumphal feat with which we know nothing to compare, except, perhaps, the composition of those marvellous master-works which Beethoven elaborated after he had become stone deaf.

Plateau's really great contributions to physical science were, however, not optical, but molecular. They were collectively republished in 1873 in two volumes, with the title, Statique expérimentale et théorique des Liquides soumis aux seules Forces moléculaires. This work was 